\title{
PROSES KEPERAWATAN DALAM MEMBERIKAN ASUHAN KEPERAWATAN
}

\author{
Fanisa Nur Siregar \\ fanisanursiregar09@gmail.com
}

\begin{abstract}
Abstrak
Asuhan keperawatan merupakan suatu proses yang sangat penting dalam memberikan pelayanan kesehatan di rumh sakit ataupun fasilitas kesehatan lainnya. Dalam memberikan asuhan keperawatan kepada kliennya perawat haruslah melalui proses-proses keperawatan yang ada. Setiap orang yang dirawat di rumah sakit berhak mendapatkan asuhan keperawatan yang diberikan oleh perawat yang bertugas. Proses keperawatan merupakan tanggung jawab seorang perawat. penerapan asuhan keperawatan dapat dikatakan baik jika perawat telah melaksanakan tahap-tahap dalam proses keperawatan kepada klien yaitu: tahap pengkajian keperwatan, tahap diagnosa keperawatan, tahap perencanaan keperawatan, tahap implementasi keperawatan, dan tahap evaluasi keperawatan.
\end{abstract}

Kata kunci : proses keperawatan, asuhan keperawatan, perawat

\section{LATAR BELAKANG}

Keperawatan adalah suatu bagian integral yang tidak dapat di bedakan dari upaya-upaya pelayanan kesehatan secara universal. Keperawatan merupakan bentuk pelayanan yang profesional bersifat humanistik, menggunakan pendekatan holistik, dilakukan berdasarkan ilmu dan kiat keperawatan, dan berorientasi kepada kebutuhan klien. Dalam melaksanakan Praktik keperawatan, harus mengacu pada standar professional keperawatan dan menggunakan etika keperawatan sebagai pedoman utama.

Perawat ditekankan untuk selalu melaksanakan asuhan keperawatan yang benar atau rasional dalam menjalankan tugasnya. Asuhan keperawatan adalah suatu proses dalam praktik keperawatan yang diberikan kepada individu untuk memenuhi kebutuhan dasarnya, dengan menggunakan sebuah tindakan proses keperawatan yang berpedoman dengan standar 
keperawatan yang telah ditentukan. Asuhan keperawatan merupakan faktor yang sangat penting dalam kelangsungan hidup pasien dan aspek-aspek dalam memelihara kesehatannya.

Proses keperawatan adalah suatu upaya pengorganisasian yang terstruktur, dalam memberikan asuhan keperawatan pada individu, kelompok maupun masyarakat yang berfokus pada identifikasi dan pemecahan masalah dari respons pasien terhadap kondisinya. Dalam melaksanakan tugasnya, seorang perawat sebelum memberikan asuhan keperawatan harus melakukan proses keperawatan berupa pengkajian, diagnosis keperawatan, intervensi, dan evaluasi. Proses asuhan keperawatan merupakan suatu tugas dan kewajiban seorang perawat untuk memberikannya dimulai dari pasien datang sampai pasien kembali pulang, melalui tahap pengkajian secara menyeluruh, kemudian menegakkan diagnosa keperawatan yang bersumber dari data pengkajian yang didapat, serta melaksanakan intervensi, implementasi dan evaluasi umtuk keefektifan diagnosa awal yang sudah ditegakkan. Dalam melakukan proses keperawatan terhadap pasien, perawat harus mampu berpikir secara kritis dan menguasai ilmu-ilmu keperawatan. Proses keperawatan terus berkembang seiring dengan berjalannya waktu. Dahulu proses keperawatan hanya ada tiga kemudian berkembang menjadi 4 dan terus berkembang menjadi 5 tahapan yaitu pengkajian, diagnosa, perencanaan, implementasi, evaluasi. Tujuan dalam melaksanakan proses keperawatan secara umum adalah untuk mengidentifikasi ataupun memeriksa status perawatan kesehatan klien (individu,kelompok, ataupun masyarakat). Dalam menentukan proses keperawatan yang akan dilakukan perawat harus berfikir dan bertindak secara sistematis.

\section{METODE}

Metode yang digunakan untuk mendapatkan informasi dalam pembuatan jurnal ini adalah menggunakan metode kepustakaan yaitu membaca dan menganalisa jurnal online, e-book, dan skripsi, thesis dan sumber lainnya yang tepat, sesuai dan berfokus kepada proses keperawatan. Dengan menggunakan jurnal dan e-book dengan terbitan paling tua tahun 2012.

\section{HASIL}

Dalam memberikan asuhan keperawatan perawat juga perlu memperhatikan proses keperawatan yang dilakukan. Penerapan asuhan keperawatan dapat dikatakan baik jika semua perawat di rumah sakit ataupun tempat pelayanan kesehatan lainnya sudah melaksanakan semua 
tahap-tahap dalam memberikan asuhan keperawatan kepada pasien yaitu: tahap pengkajian keperwatan, tahap diagnosa keperawatan, tahap perencanaan keperawatan, tahap implementasi keperawatan, dan tahap evaluasi keperawatan. Proses keperawatan adalah suatu upaya pengorganisasian yang terstruktur, dalam memberikan asuhan keperawatan pada individu, kelompok maupun masyarakat yang berfokus pada identifikasi dan pemecahan masalah dari respons pasien terhadap kondisinya. Memberikan asuhan keperawatan berdasarkan proses keperawatan merupakan kewajiban dan tugas perawat. Proses keperawatan ini dilakukan dari awal pasien masuk kerumah sakit sampai pasien pulang kerumahnya. Dalam melakukan proses keperawatan, dipengaruhi oleh beberapa faktor yaitu pengetahuan, sarana dan prasarana, serta sikap. Pelaksanaan proses kperawatan ini harus berurutan. Diluar negeri istilah proses keperawatan ini di perkenalkan pada tahun 1955 oleh Lidya Hall. Yura and Walsh (1983) yang menyebutkan proses keperawatan terdiri atas 4 tahap. Perkembangan selanjutnya pada tahun 1982 melalui National Council of State Boards of Nursing menyatakan bahwa proses keperawatan terdiri atas 5 tahap yaitu pengkajian keperawatan, diagnosa keperawatan, perencanaan keperawatan, implementasi dan evaluasi keperawatan.

Dahulu proses keperawatan hanya ada tiga kemudian berkembang menjadi 4 dan terus berkembang menjadi 5 tahapan yaitu pengkajian, diagnosa, perencanaan, implementasi, evaluasi. Setiap orang berhak mendapatkan asuhan keperawatan berdasarlan proses keperawatan. Tujuan dari pemberian proses keperawatan adalah untuk mengindentifikasi dan untuk mengetahui status perawatan kesehatan klien dan masalah kesehatan yang aktual dan potensial, serta untuk membuat rencana untuk memenuhi kebutuhan yang di butuhkan dan memberikan intervensi keperawatan yang akurat untuk memenuhi kebutuhan tersebut. sifat dari proses keperawatan adalah terbuka dan fleksibel, dilakukan melalui pendekatan individual,penanganan masalah yang terencana,mempunyai arah dan tujuan,terdapat validasi data dan pembuktian masalah.

\section{PEMBAHASAN}

Asuhan keperawatan merupakan suatu proses keperawatan yaitu suatu cara yang sistematis dan ilmiah yang digunakan perawat untuk memenuhi kebutuhan dasar klien untuk mencapai atau mempertahankan keadaan biologis, psikologis, sosial dan spiritual yang optimal. Proses keperawatan adalah suatu upaya pengorganisasian yang terstruktur, dalam memberikan asuhan keperawatan pada individu, kelompok maupun masyarakat yang berfokus pada 
identifikasi dan pemecahan masalah dari respons pasien terhadap kondisinya. Dalam memberikan asuhan keperawatan perawat juga harus memperhatikan proses keperawatan. Proses keperawatan tidak hanya dilakukan di rumah sakit, tetapi dilakukan di tempat pelayanan kesehatan lainnya seperti puskesmas.

Diluar negeri istilah proses keperawatan ini di perkenalkan pada tahun 1955 oleh Lidya Hall. Pada awal perkembangannya, proses keperawatan mempunyai tiga tahap, selanjutnya empat tahap dan pada saat ini proses keperawatan mempunyai lima tahap. Proses lima tahap dalam proses keperawatan pertama kali diperkenalkan pada tahun 1967 oleh Western Interstate Commision of Higher Education (WICHE) yaitu berupa: persepsi, komunikasi, interpretasi, intervensi, dan evaluasi. Di tahun yang sama, para staff pengajar, Yura.H dan Walsh di Catholic University of American memberikan usulnya yaitu metode empat tahap, meliputi: pengkajian, perencanaan, intervensi dan evaluasi (Craven \&Hirnle, 2000). Pada tahun 1973, American Nurse's Association (ANA) menerbitkan standars of Nursing Practice dan juga National Council of State Boards of Nursing (1982 ) yang terdiri dari lima tahap, meliputi: pengkajian, diagnosa keperawatan, perencanaan, implementasi dan evaluasi yang digunakan sampai saat ini. (Kozier et al., 1995). Berikut adalah penjelasan lebih lanjut mengenai proses keperawatan.

\section{Pengertian}

Proses keperawatan adalah metode atau cara yang dilakukan oleh perawat yang bersifat ilmiah, sistematis, dinamis dan terus menerus serta berkesinambungan dalam rangka pemecahan masalah kesehatan agar kebutuhan dasar pasien tetap terpenuhi.

\section{Tujuan}

Tujuan dari pemberian proses keperawatan adalah untuk mengindentifikasi dan untuk mengetahui status perawatan kesehatan klien dan masalah kesehatan yang aktual dan potensial, serta untuk membuat rencana untuk memenuhi kebutuhan yang di butuhkan dan memberikan intervensi keperawatan yang akurat untuk memenuhi kebutuhan tersebut . pelaksanaan proses keperawatan ini juga bertujuan untuk menghasilkan asuhan keperawatan yang berkualitas dan bermutu sehingga berbagai masalah kebutuhan klien dapat teratasi. Untuk mencapai suatu kebutuhan secara umum, dalam proses keperawatan terdapat beberapa tujuan khusus yang sesuai dengan tahapan dari proses keperawatan, diantaranya yaitu : 
a. Dapat mengindentifikasi berbabagai kebutuhan dasar manusia yang dibutuhkan klien

b. Dapat menentukan diagnosis keperawatan yang ada pada manusia setelah dilakukan identifikasi di tahap awal

c. Dapat menentukan rencana tindakan yang akan dilakukan setelah diagnosis keperawatan ditentukan

d. Dapat melaksanakan tindakan keperawatan setelah direncanakan

e. Dapat mengetahui perkembangan pasien dari berbagai individu tindakan yang telah dilakukan, untuk menentukan tingkat keberhasilan.

\section{Manfaat}

Proses keperawatan ini memiliki manfaat tersendiri bagi perawat yang memberikan dan terhadap klien yang menerimanya. Berikut adalah manfaatnya :

a. Perawat akan mempunyai rasa percaya diri yang baik. Perawat merasa lebih percaya diri melaksanakan tindakan asuhan keperawatan.

b. Adanya proses keperawatan yang sistematis, perawat akan memberikan peningkatan kualitas asuhan keperawatan. Asuhan keperawatan yang optimal, akan mempercepat proses pemulihan kesehatan klien.

c. Proses keperawatan yang diterapkan akan membantu pengembangan profesionalisme perawat.

d. Klien akan ikut berpartisipasi dalam menentukan perencanaan keperawatan yang akan dilaksanakan

e. Proses keperawatan menjamin klien akan mendapatkan asuhan keperawatan yang berkesinambungan.

f. Klien akan mendapatkan kualitas pelayanan asuhan keperawatan yang prima

\section{Tahap-tahap proses keperawatan}

\section{a) Pengkajian}

Pengkajian keperawatan merupakan tahap pertama yang harus dilakukan oleh perawat saat pasien masuk di rumah sakit maupun pusat pelayanan kesehatan lainnya. Pengkajian tersebut merupakan peroses dari pengumpulan data dari klien. Seperti nama dan umur pasien, verifikasi, dan komunikasi data tentang pasien. Dalam melakukan pengkajian perawat haruslah 
teliti dan cermat dalam pengumpulan data, karena dari tahap inilah kita dapat mengetahui kemana arah tindakan yang dapat di lakukan. Pengkajian adalah suatu upaya pengumpulan data secara lengkap, akurat dan sistematis terhadap individu untuk dikaji dan dianalisis sehingga masalah kesehatan yang dihadapi dapat di selesaikan. Adapun langkah-langkah dalam pengkajian yaitu:

- Mengumpulkan data

- Pengelompokan/mengatur data

- Validasi data

- Mendokumentasikan data

b) Diagnosa Keperawatan

Diagnosis keperawatan di tentukan berdasarkan pengkajian. Diagnosa keperawatan adalah suatu penilaian klinis yang menggambarkan tentang respons yang diberikan oleh individu, keluarga, atau kelompok terhadap masalah kesehatan atau proses kehidupan aktual ataupun potensial sebagai dasar pemilihan intervensi keperawatan secara tepat untuk menjaga status kesehatan klien. Diagnosa keperawatan terdiri dari masalah, penyebab, dan tanda atau gejala yang muncul dalam pengkajian. Data hasil pengkajian ditelaah melalui proses analisis sebagai dasar untuk mengindentifikasi diagnosis keperawatan.

c) Perencanaan Keperawatan

Perencanaan keperawatan merupakan tahap ketiga dalam proses keperawatan. Rencana asuhan keperawatan merupakan tahap antara penetapan kebutuhan klien dan pelaksanaan tindakan keperawatan yang diberikan. Rencana tindakan keperawatan adalah suatu proses penyusunan strategi atau intervensi keperawatan berdasarkan kebutuhan dasar yang dibutuhkan untuk mencegah, mengurangi atau mengatasi masalah kesehatan pasien yang telah diidentifikasi dan validasi pada tahap pengkajian dan pemberian diagnosa keperawatan. Perencanaan meliputi pengembangan strategi untuk mencegah, mengurangi, atau mengoreksi masalah-masalah yang telah diidentifikasi pada diagnosis keperawatan. Tahap ini dimulai setelah menentukan diagnosis keperawatan dan menyimpulkan rencana dokumentasi. 


\section{d) Implementasi}

Implementasi merupakan langkah keempat dalam tahap proses keperawatan dengan melaksanakan berbagai strategi keperawatan (tindakan keperawatan) yang telah direncanakan dalam rencana tindakan keperawatan. Implementasi merupakan serangkaian kegiatan yang dilakukan oleh perawat berdasarkan tindakan yang telah di rencanakan di tahap intervensi sebelumnya, implementasi terdiri dari melakukan dan mendokumentasikan tindakan yang diberikan merupakan suatu tindakan keperawatan khusus yang diperlukan untuk melaksanakan intervensi keperawatan. Perawat melaksanakan tindakan keperawatan untuk melakukan intervensi yang disusun dalam tahap perencanaan dan kemudian mengakhiri tahap implementasi dengan mencatat tindakan keperawatan dan respons klien terhadap tindakan yang telah diberikan. Adapun proses pada implementasi, diantaranya:

- Mengkaji kembali klien

- Menentukan kebutuhan perawatan terhadap bantuan

- Mengimplementasikan intervensi keperawatan

- Melakukan supervisi terhadap asuhan yang didelegasikan

- Mendokumentasikan tindakan keperawatan

e) Evaluasi

Evaluasi merupakan tahap akhir dari proses pelaksanaan asuhan keperawatan yang bertujuan untuk mengevaluasi atau melihat tingkat keberhasilan dari tindakan keperawatan yang diberikan. Penyunan rencana keperawatan yang baru apabila tindakan yang dilakukan sebelumnya tidak atau belum berhasil. Yang dinilai dalam evaluasi tersebut berupa kognitif, afektif, dan psikomotor. Sedangkan tiindakan yang dapat dievaluasi secara langsung isetelah tindakan diberikan ialah pendidikan kesehatan. Apabila hasil dari evaluasi perawat perlu melakukan tindak lanjut dengan melakukan kunjungan rumah, maka perawat harus membuat perencanaan kunjungan (Riasmini, et al., 2017).

\section{Sifat Proses Keperawatan}

Proses keperawatan mempunyai sifat. Adapun sifat dari proses keperawatan adalah sebagai berikut: 
a. Terbuka dan fleksibel. Proses keperawatan menganut sistem yang terbuka. Jika nanti terjadi perubahan respon pada klien maka akan memberikan perubahan terhadap diagnosayang telah ditetapkan, rencana dan tindakan yang akan perawat diberikan. Fleksibel karena semua rencana yang telah Anda susun tidak harus dilaksanakan seluruhnya, tetapi harus melihat perubahan dan perkembangan pada kondisi klien.

b. Dilakukan melalui pendekatan individual. Berhubungan dengan masalah yang dihadapi klien, ada banyak hal yang bersifat individual dan merupakan privasi dari klien. Sehingga tidak kepada semua perawat mendapat kepercayaan dari klien, atau tidak semua data (yang sehubungan dengan masalah keperawatan) akan disampaikan oleh klien kepada perawat. Pada situasi seperti ini maka dibutuhkan suatu pendekatan yang individual kepada klien. Kemudian perawat harus mampu membina hubungan saling percaya dengan klien.

c. Penanganan masalah yang terencana. Setelah masalah keperawatan ditemukan, yang ditunjang oleh data-data senjang yang merupakan karakteristik dari masalah. Selanjutnya perawat akan menyusun perencanaan yang berlandaskan kepada ilmu keperawatan yang kokoh. Semua perencanaan yang disusun berdasarkan konsep keilmuan dan profesionalisme Anda sebagai seorang perawat.

d. Mempunyai arah dan tujuan. Perencanaan yang Anda susun mempunyai arah dan tujuan yang akan dicapai dalam batasan waktu tertentu demi tercapainya kesehatan yang optimal bagi klien.

e. Terdapat validasi data dan pembuktian masalah. Selalu ada pengkajian ulang terhadap data yang didapat. Data yang dikumpulkan pada saat pengkajian merupakan betul-betul data yang diperoleh dari alat yang terukur dan diperoleh oleh perawat. Masalah keperawatan harus di kenali dari batasan karakteristiknya masing-masing. Kemudian perawat harus menegakkan sebuah diagnosa keperawatan jika telah ditemukan batasan karakteristiknya

\section{PENUTUP}

Penerapan asuhan keperawatan dikatakan baik apabila perawat sudah melaksanakan tahaptahap dalam memberikan asuhan keperawatan kepada pasien yaitu: tahap pengkajian keperwatan, tahap diagnosa keperawatan, tahap perencanaan keperawatan, tahap implementasi 
keperawatan, dan tahap evaluasi keperawatan. Asuhan keperawatan adalah kerangka kerja dan struktur organisasi yang kreatif untuk memberikan pelayanan keperawatan, namun asuhan keperawatan juga cukup fleksibel untuk digunakan disemua lingkup keperawatan. Keperawatan sebagai proses, diperkenalkan sejak tahun 1955 oleh Hall dan pada tahun 2004 proses keperawatan (nursing process) ditetapkan sebagai series of steps oleh ANA (American Nursing Association) (Wilkinson, 2007), yang terdiri dari assesment (pengkajian), diagnosis (penetapan diagnosis), planning outcomes (perencanaan hasil), planning intervention (perencanaan intervensi), implementation (implementasi) dan evaluation (evaluasi). Pada prakteknya kegiatan proses keperawatan di atas tidaklah selalu berurutan tetapi bisa dikerjakan pada waktu bersamaan/tumpang tindih (overlapping).

Salah satu kegiatan yang penting dalam proses keperawatan adalah pengkajian keperawatan. Pengkajian keperawatan ini sangat penting karena dari pengkajian keperawatan maka perawat akan mampu menentukan apa keperawatan/diganosa keperawatan dan masalah kolaboratif/diagnosis potensial komplikasi yang dialami oleh pasien dan membuat perencanaan dalam merawat pasien.

\section{DAFTAR PUSTAKA}

Achmadi, L., dkk. (2015). Gambaran tingkat pengetahuan perawat dalam penerapan standar asuhan keperawatan diruangan rawat inap interna RSUD Datoe Bhinangkang. E-Journal Keperawatan (e-Kp) Vol (3) No (3)

Apriyani, H. (2015). Identifikasi Diagnosis Keperawatan Pada Pasien Di Ruang Paru Sebuah Rumah Sakit. Jurnal Keperawatan, Volume Xi, No. 1, 107-111.

Astar, F., \& dkk. (2018). Pengaruh Pelayanan Asuhan Keperawatan Terhadap. Journal of Management Vol. 1 No. 2, 33-57.

Budiono. (2016). Konsep Dasar Keperawatan. Jakarta : Bumi Medika.

Kusnadi, E. (2017). Analisis Kelengkapan Dokumentasi Keperawatan Di Ruang Rawat Inap. Jurnal Bidang Ilmu Kesehatan Vol. 9, No. 1, 553-561. 
Rezky. (2018). Gambaran Faktor Yang Mempengaruhi Pelaksanaan Asuhan Keperawatan Individu Di Puskesmas Kota Makassar. Skripsi-Universitas Hasanuddin Makassar. Makassar: Tidak Dipublikasikan.

Salmawati. (2013). Faktor Yang Berhubungan Dengan Pelaksanaan Dokumentasi Asuhan Keperawatan Di Ruang Perawatan Rsud Labuang Baji Makassar. Skripsi-Uin Alauddin Makassar. Makassar: Tidak Dipublikasikan.

Simamora, R. H. (2019). Development of Guidelines for Applying appropriate Patient Identification to Achieve Patient Safety Goal INC 201912 th International Nursing Conference.2019.10 455-455(1 pages) $\quad$ UCI(KEPA): I410-ECN-0101-2019-512001224337.

Simamora. R. H. (2008) The correlation of ward chief's giving direction and command and the performance of on-duty nurses at Jember dr. Subandi general hospital inpatient wards. jurnal Administrasi dan Kebijakan Kesehatan, (https://fkm.unair.ac.id/jurnal-administr)

Susiana, E. (2013).Faktor Yang Berhubungan Dengan Mutu Pendokumentasian Asuhan Keperawatan Di Rsud Dr. Soetomo Surabaya. Skripsi- Universitas Airlangga Surabaya. Surabaya: Tidak Dipublikasikan.

Wirdah, H., \& Yusuf, M. (2016). Penerapan Asuhan Keperawatan Oleh Perawat Pelaksana Di Rumah Sakit Banda Aceh. Jurnal Ilmiah Fakultas Keperawatan Vol 1, No 1, 1-6.

Wulandari, P., \& dkk. (2016). Faktor-Faktor Yang Berhubungan Dengan Pendokumentasian Asuhan Keperawatan Di Rumah Sakit Jiwa. NERS JURNAL KEPERAWATAN,Volume 12, No.2, 131-142. 